\title{
HUBUNGAN ANTARA PENGETAHUAN DENGAN PELAKSANAAN SISTEM LIMA MEJADI POSYANDU BALITA KELURAHAN NGRONGGO KECAMATAN KOTA KOTA KEDIRI
}

(The relationship between knowledge and implementation the five tables systems in Posyandu balita the Ngronggo Village, Kediri)

Dwi Rahayu, Moh. Alimansur, Fajar Rinawati

\section{ABSTRACT}

Posyandu is a place to get basic services, especially in areas that are managed by the public health. Posyandu function is not optimal in fourth table or a healt promotion table has not been fully utilized by the cadres. Many of those who did not provide information at the time of weighing every month.

The purpose of this study was to determine the relationship between knowledge and implementation the five tables systems in Posyandu balita the Ngronggo Village, Kediri. The population in this study is all cadres posyandu balita who was in the district Ngronggo Kediri which totaled 57 people. Number of samples taken as many as 52 people. The sampling technique used is proportioned random sampling.

Analysis of the relationship between knowledge and implementation the five tables systems is Spearman rho correlation. From the processing of the analysis statistic obtained probability value is more than 0.05 , which means there is no relationship between knowledge and implementation the five tables systems in Posyandu balita the Ngronggo Village, Kediri City.

The results showed the cadres who have obtained the information and training has been attempted to try (trial) and try to adopt all the knowledge gained to apply when posyandu but because it is constrained by a variety of conditions such as facilities and infrastructure, the less number of cadres, many cadres who had elderly so that their knowledge can not be fully used when posyandu

Keywords: Five table system, knowledge, Posyandu balita

\section{Latar Belakang}

Dalam rangka menuju masyarakat yang adil dan makmur maka pembangunan dilakukan disegala bidang yang salah satunya adalah pembangunan di bidang kesehatan. Pembangunan dibidang kesehatan mempunyai arti yang sangat penting dalam kehidupan nasional, khususnya dalam memelihara dan meningkatkan kesehatan. Dalam rangka mencapai keberhasilan tersebut, erat kaitannya dengan pembinaan dan pengembangan sumber daya manusia sebagai modal dasar pembangunan nasional. Pengembangan sumber daya manusia merupakan suatu upaya yang besar, sehingga tidak hanya dilakukan oleh pemerintah saja tanpa adanya keterlibatan masyarakat. Upaya menggerakkan masyarakat dalam keterpaduan secara operasional dibentuklah Pos Pelayanan Terpadu (Posyandu). Posyandu merupakan wadah untuk mendapatkan pelayanan dasar terutama dalam bidang kesehatan yang dikelola oleh masyarakat, sedangkan penyelenggaraanya dilaksanakan oleh kader yang telah dilatih dibidang kesehatan, dimana anggotanya berasal dari PKK, tokoh masyarakat dan pemudi. (Zulkifli, 2003)

Dinas Kesehatan Kota Surabaya masih merasa fungsi Posyandu berjalan tidak optimal. Meja keempat atau meja penyuluhan selama ini belum dimanfaatkan penuh oleh kader Posyandu. 
Banyak diantara mereka yang tidak memberikan penyuluhan pada saat penimbangan rutin setiap bulan. Hal tersebut diungkapkan oleh Kepala Bidang Kesehatan Masyarakat dr. Sri Setiyani. Beliau mengungkapkan banyak Posyandu di Surabaya yang fungsi meja keempatnya kurang optimal. Kebanyakan yang datang di Posyandu cuma daftar, timbang, dan dicatat. Itu semua adalah fungsi meja 1, 2, dan 3, meja 4 kurang berfungsi.

Berdasarkan hasil wawancara dengan pemegang program Posyandu, tanggal 8 Juni 2009, di Puskesmas Kota Wilayah Selatan, mengungkapkan bahwa di Kelurahan Ngronggo ada 12 Posyandu Balita dengan jumlah kader sebanyak 63 orang yang harus memperhatikan bayi dan balita sebanyak 875 anak. Kegiatan Posyandu belum melaksanakan sistem lima meja, padahal pada tahun 2006 pernah diadakan pelatihan pelaksanaan sistem lima meja. Pemegang program juga mengungkapkan bahwa belum ada dukungan yang nyata dari Kelurahan, misalnya belum ada dana dari Kelurahan untuk membantu Pemberian Makanan Tambahan (PMT) bagi bayi dan balita. Sementara itu bantuan dari Daerah berupa food model dan panggung boneka belum digunakan secara maksimal. Selain itu pemegang program juga mengeluhkan tentang kondisi kader yang sebagian besar sudah tua, sehingga penerimaan informasi dan pelaksanaan kurang maksimal.

Tidak optimalnya fungsi Posyandu, terutama meja IV, sangat disayangkan, karena Posyandu menjadi garda terdepan untuk meningkatkan derajat kesehatan bayi dan balita. Sebab meja itu dipergunakan untuk memberikan penyuluhan kesehatan mengenai kondisi anak setelah ditimbang di Posyandu. Dengan tidak adanya penyuluhan saat penimbangan rutin setiap bulan di Posyandu, anak yang memiliki gejala kurang gizi jadi tidak bisa diintervensi lebih lanjut. Padahal seharusnya orang tua anak tersebut diperingatkan, sehingga akhirnya sang anak tidak jadi kurang gizi.
Selain itu, anak yang sedang sakit saat penimbangan juga tidak mendapatkan perhatian lebih. Padahal, dengan memberikan perhatian pada anak yang sakit dan memberikan sedikit penyuluhan bisa membentuk ikatan emosional kepada orang tua, sehingga orang tua lebih bersemangat menimbangkan anaknya di Posyandu atau memeriksakannya ke Petugas yang berkaitan. (Dinkes Kota Surabaya, 2008)

Berdasarkan latar belakang di atas peneliti tertarik untuk meneliti sejauh mana hubungan antara pengetahuan dan pelaksanaan sistem lima meja pada kader posyandu di Posyandu Kelurahan Ngronggo Kecamatan Kota, Kota Kediri.

\section{Rumusan Masalah}

Rumusan masalah yang diambil adalah "Adakah hubungan antara pengetahuan dan pelaksanaan sistem lima meja di Posyandu Kelurahan Ngronggo Kecamatan Kota, Kota Kediri?".

\section{Tujuan penelitian}

Tujuan dari penelitian ini adalah untuk mengetahui hubungan antara pengetahuan dan pelaksanaan sistem lima meja di Posyandu Kelurahan Ngronggo Kecamatan Kota, Kota Kediri

\section{Definisi Konseptual}

\section{Pengetahuan Kader Posyandu tentang Sistem Lima Meja}

Pengetahuan adalah merupakan hasil "tahu" dan ini terjadi setelah orang melakukan penginderaan terhadap suatu objek tertentu. Pengetahuan atau kognitif merupakan domain yang sangat penting untuk terbentuknya tindakan seseorang (Notoatmodjo, 2003).

Kader kesehatan yaitu kader-kader yang dipilih oleh masyarakat menjadi penyelenggara posyandu (Zulkifli, 2003). Kader kesehatan dinamakan juga promotor kesehatan desa (prokes) adalah tenaga sukarela yang dipilih oleh dari masyarakat dan bertugas mengembangkan masyarakat (Zulkifli, 2003). Direktorat 
bina peran serta masyarakat DepKes RI memberikan batasan kader adalah warga masyarakat setempat yang dipilih dan ditinjau oleh masyarakat dan dapat bekerja secara sukarela (Zulkifli, 2003).

Sistem 5 meja yaitu meja I: pendaftaran, meja II: penimbangan, meja III: pengisian KMS, meja IV: penyuluhan perorangan berdasarkan KMS, dan meja V: Pelayanan KB \& kesehatan lain.

\section{Pelaksanaan Sistem Lima Meja}

1) Meja I: Pendaftaran Ibu hamil/Balita

a. Kader mendaftar bayi/balita yang dibawa ibu-ibu, menuliskan nama bayi/balita pada secarik kertas dan diselipkan pada KMS/buku KIA. Apabila peserta baru, berikan buku KIA/KMS baru dan tuliskan namanya, kemudian selipkan secarik kertas bertuliskan nama bayi/balita pada buku KIA/KMS.

b. Kader mendaftar ibu hamil: menulis nama ibu hamil pada formulir atau register ibu hamil. Apabila ibu hamil tidak membawa balita, langsung dipersilahkan menuju ke meja 4. Untuk ibu hamil baru, atau belum mempunyai buku KIA berikan buku KIA.

c. Setelah mendaftar di meja 1, kemudian ibu-ibu dengan balitanya menuju meja 2

2) Meja II: Penimbangan Balita

a. Kader di meja 2 menimbang balita dan mencatat hasil penimbangan di secarik kertas yang telah diselipkan di buku KIA/KMS

b. Setelah selesai ditimbang ibu dan balita, dipersilahkan untuk menuju meja 3

3) Meja III: Pencatatan Buku KIA/KMS

a. Kader di meja 3 mencatat hasil timbangan yang ada di secarik kertas dipindahkan kedalam buku $\mathrm{KIA} / \mathrm{KMS}$. Cara pengisian buku
KIA/KMS, sesuai dengan petunjuk petugas kesehatan

b. Setelah selesai, buku KIA/KMS diserakhan kembali dan dipersilahkan menuju meja 4

4) Meja IV: Penyuluhan

a. Kader di meja 4 memberikan penyuluhan kepada ibu, sesuai dengan hasil pencatatan di buku KIA/KMS dan pengamatan terhadap anaknya

b. Penyuluhan ini tidak hanya diberikan kepada balita yang tidak naik/turun timbangannya, tetapi yang timbangannya naik pun juga perlu diberi penyuluhan untuk dapat menjaga kesehatannya. Di meja 5 kader dapat melakukan rujukan ke tenaga kesehatan, bidan, PLKB atau Puskesmas pada kasus-kasus yang perlu dirujuk

c. Topik penyuluhan yang diberikan sesuai dengan permasalahan yang ada

d. Kader juga dapat memberikan penyuluhan gizi, atau pertolongan dasar, misalnya pemberian makanan tambahan (PMT), vitamin, oralit, menurunkan demam ringan pada anak, meredakan batuk dsb.

e. Berikan pujian pada balita/ibunya, bila mereka rajin menimbang dan bagus nilai timbangannya atau perkembangannya.

5) Meja V: Pelayanan Kesehatan

a. Dilakukan khusus di meja 5, yang memberikan pelayanan adalah petugas kesehatan, bidan atau PLKB

b. Layanan yang diberikan antara lain: imunisasi, KB, Pemeriksaan ibu hamil, Pemberian tablet tambah darah, kapsul yodium dll.

\section{Metode Penelitian}

Berdasarkan tujuan penelitian, maka peneliti akan menggunakan metode corelasional yang mengkaji hubungan 
antara dua variabel korelatif antar variabel. (Nursalam, 2003: 84-85). Dalam penelitian ini yang dikorelasikan adalah pengetahuan dan pelaksanaan sistem lima meja pada kader posyandu balita. Penelitian ini menggunakan pendekatan cross sectional yaitu suatu penelitian dimana variabel-variabel yang termasuk efek diobservasi sekaligus pada waktu yang sama. Pada penelitian ini variabel pengetahuan kader posyandu balita dan variabel pelaksanaan sistem lima meja pada kader posyandu balita diteliti sekaligus pada waktu yang sama (Notoatmodjo, 2005). Penelitian ini menilai tingkat pengetahuan kader posyandu balita tentang sistem lima meja, kemudian menilai pelaksanaan sistem lima meja pada saat itu.

Populasi dalam penelitian ini adalah seluruh kader posyandu balita yang berada di Kelurahan Ngronggo Kota Kediri yang berjumlah 57 orang. Besar sample dihitung dengan rumus:

$$
\mathrm{n}=\frac{N}{1+N \cdot\left(d^{2}\right)}
$$

Keterangan: $\mathrm{N}$ : besar populasi

n: besar sempel

d: tingkat kepercayaan / ketepatan yang diinginkan

2005: 92)

(Notoatmodjo,

$$
\begin{aligned}
& \mathrm{n}=\frac{57}{1+36 \cdot(0,05)^{2}} \\
& =\frac{57}{1+(36 \cdot 0,0025)} \\
& =\frac{57}{1,09}
\end{aligned}
$$$$
=52
$$

Jadi jumlah sampel yang diambil sebanyak 52 orang. Tehnik pengambilan sampel yang digunakan adalah Proportioned random sampling.

Analisis adanya hubungan antara pengetahuan dan pelaksanaan sistem lima meja adalah dengan menggunakan korelasi rho-spearman, dengan bantuan SPSS 17 For Windows.

\section{Hasil Penelitian}

Penelitian tentang "Hubungan antara pengetahuan Kader Posyandu dan Pelaksanaan Sistem Lima Meja di Posyandu Balita Kelurahan Ngronggo Kecamatan Kota, Kota Kediri.”. Penelitian ini menggunakan 12 posyandu dengan jumlah 52 responden yang memenuhi kriteria inklusi.

\section{Karakteristik Responden}

\section{Berdasarkan Usia}

Tabel 4.1 Distribusi Frekuensi Responden berdasarkan usia

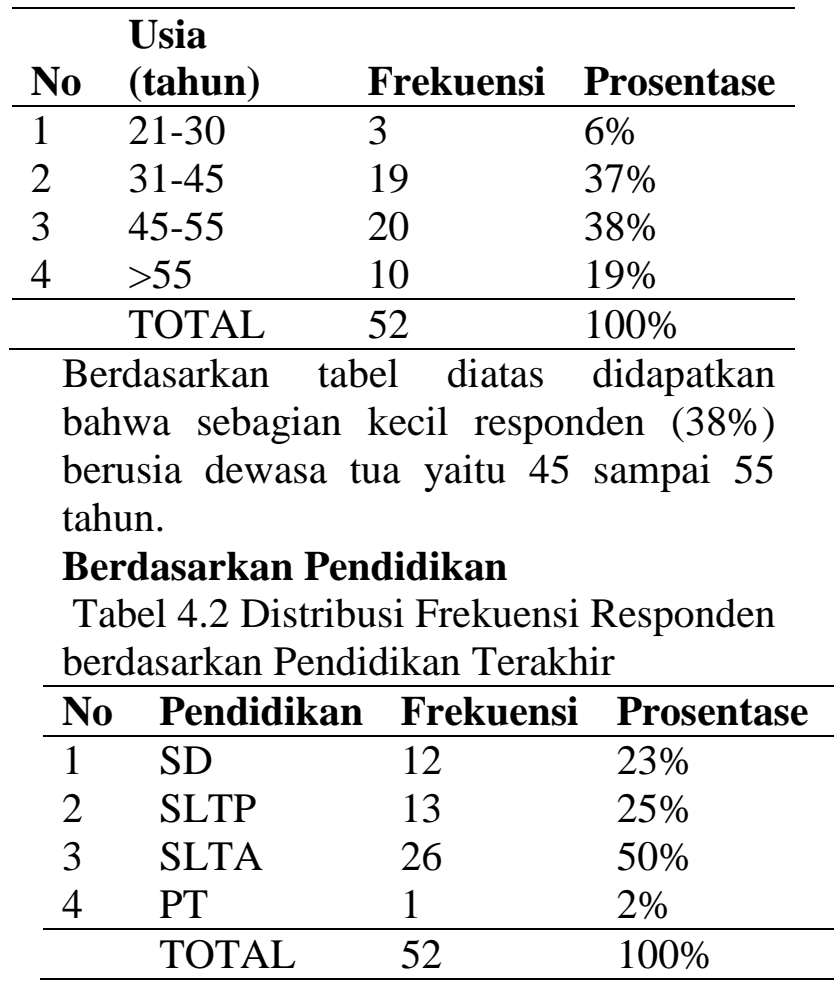

Berdasarkan tabel di atas didapatkan bahwa sebagian responden (50\%) mempunyai pendidikan terakhir SLTA. 


\section{Berdasarkan Pernah Tidaknya Mengikuti Pelatihan Kader}

Tabel 4.3 Distribusi Frekuensi Responden berdasarkan Pelatihan Kader

\begin{tabular}{llcc}
\hline & Pelatihan & & \\
No & Kader & Frekuensi & Prosentase \\
\hline 1 & Pernah & 33 & $63 \%$ \\
2 & Tidak pernah & 19 & $37 \%$ \\
\hline & total & 52 & $100 \%$ \\
\hline
\end{tabular}

Berdasarkan tabel di atas didapatkan bahwa sebagian besar responden $(63 \%)$ pernah mengikuti pelatihan posyandu.

\section{Berdasarkan Paparan Informasi}

Tabel 4.4 Distribusi Frekuensi Responden berdasarkan Paparan Informasi

\begin{tabular}{|c|c|c|c|}
\hline No & $\begin{array}{l}\text { Paparan } \\
\text { Informasi }\end{array}$ & Frekuensi & Prosentase \\
\hline 1 & Pernah & 32 & $62 \%$ \\
\hline 2 & Tidak pernah & 20 & $38 \%$ \\
\hline & total & 52 & $100 \%$ \\
\hline $\begin{array}{l}\text { did } \\
\text { res } \\
\text { inf } \\
\text { Lin }\end{array}$ & $\begin{array}{l}\text { Berdasarkan } \\
\text { patkan bahwa } \\
\text { onden }(62 \%) \\
\text { masi tentang } \\
\text { Meja dalam pc }\end{array}$ & $\begin{array}{l}\text { tabel } \\
\text { a sebaga } \\
\text { pernah m } \\
\text { Pelaksana } \\
\text { osyandu. }\end{array}$ & 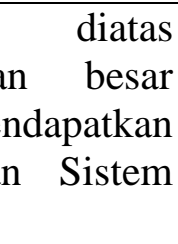 \\
\hline
\end{tabular}

\section{Berdasarkan Sumber Informasi Yang diperoleh}

Tabel 4.5 Distribusi Frekuensi Responden berdasarkan Sumber Informasi

\begin{tabular}{llll}
\hline & Sumber & & \\
No & Informasi & Frekuensi & Prosentase \\
\hline 1 & Kelurahan & 19 & $59 \%$ \\
2 & Yankes & 9 & $28 \%$ \\
3 & Pelatihan & 4 & $13 \%$ \\
\hline & Total & 32 & $100 \%$ \\
\hline
\end{tabular}

Dari tabel diatas didapatkan bahwa sebagian besar responden (59\%) pernah mendapatkan informasi tentang sistem lima meja dari kelurahan.
Tingkat Pengetahuan Responden

Tabel 4.6 Distribusi Frekuensi Responden berdasarkan Pengetahuan

\begin{tabular}{llcc}
\hline No & Pengetahuan & Frekuensi & Prosentase \\
\hline 1 & Baik & 2 & $16,67 \%$ \\
2 & Cukup baik & 3 & $25 \%$ \\
3 & Kurang baik & 6 & $50 \%$ \\
4 & Tidak baik & 1 & $8,30 \%$ \\
\hline & Total & 12 & 100 \\
\hline
\end{tabular}

Dari tabel diatas dapat diketahui bahwa sebagian responden (50\%) mempunyai pengetahuan yang kurang baik tentang sistem 5 meja dalam posyandu.

\section{Pelaksanaan Sistem Lima Meja}

Tabel 4.7 Distribusi Frekuensi Responden berdasarkan Pelaksanaan Sistem Lima Meja

\begin{tabular}{llll}
\hline & Pelaksanaan & & \\
No & Sistem 5 meja & Frekuensi & Prosentase \\
\hline 1 & Baik & 0 & $0 \%$ \\
2 & Cukup & 0 & $0 \%$ \\
3 & Kurang & 12 & $100 \%$ \\
\hline & Total & 12 & $100 \%$ \\
\hline
\end{tabular}

Dari tabel diatas didapatkan bahwa seluruh posyandu (100\%) kurang dalam pelaksanaan sistem lima meja.

\section{Hubungan Pengetahuan dengan Pelaksanaan Sistem Lima Meja}

Tabel 4.8 hubungan antara pengetahuan dan pelaksanaan sistem lima meja di posyandu balita kelurahan ngronggo kecamatan kota kota Kediri

\begin{tabular}{|c|c|c|c|c|}
\hline & & & \multicolumn{2}{|c|}{ Pengetahuan Pelaksanaan } \\
\hline \multirow{8}{*}{$\begin{array}{l}\text { Spearman' } \\
\text { s rho }\end{array}$} & Pengetahua & Correlation & 1,000 & ,317 \\
\hline & $\mathrm{n}$ & Coefficient & & \\
\hline & & Sig. (2-tailed & & ,316 \\
\hline & & $\mathrm{N}$ & 12 & 12 \\
\hline & Pelaksanaa & Correlation & ,317 & 1,000 \\
\hline & $\mathrm{n}$ & Coefficient & & \\
\hline & & Sig. (2-tailed &, 316 & 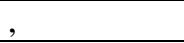 \\
\hline & & $\mathrm{N}$ & 12 & 12 \\
\hline
\end{tabular}

Dari tabel tersebut dapat dilihat bahwa nilai probabilitasnya lebih dari 0,05 yang artinya tidak ada hubungan antara pengetahuan dan pelaksanaan sistem lima 
meja di Posyandu Balita Kelurahan Ngronggo Kecamatan Kota Kota Kediri.

\section{Pembahasan}

Setelah hasil penelitian diuji dengan memakai analisis nonparametric correlation dari Spearman (Spearman Rank Correlation), didapatkan nilai koefisien korelasi Spearman $\left(\mathrm{r}_{\mathrm{s}}\right)$ sebesar 0,317 yang berarti makin tinggi pengetahuan Kader Posyandu tentang Sistem Lima Meja maka semakin baik pula Pelaksanaan Sistem Lima Meja di Posyandu Balita Kelurahan Ngronggo Kecamatan Kota Kota Kediri. Sedangkan nilai probabilitas dalam penelitian ini adalah 0,316, karena 0,316>0,05 maka $\mathrm{H}_{0}$ diterima dan $\mathrm{H}_{1}$ ditolak yang berarti tidak ada hubungan yang signifikan antara pengetahuan Kader Posyandu tentang Sistem Lima Meja dengan Pelaksanaan Sistem Lima Meja di Posyandu Balita Kelurahan Ngronggo Kecamatan Kota Kota Kediri

Menurut pendapat Benyamin Bloom dalam Notoatmodjo (2004) bahwa terbentuknya perilaku baru, terutama pada orang dewasa dimulai pada domain kognitif, dalam arti subjek tahu terlebih dahulu terhadap stimulus yang berupa materi atau objek di luarnya. Sehingga menimbulkan pengetahuan baru pada subjek tersebut, dan selanjutnya menimbulkan respon batin dalam bentuk sikap si subjek terhadap objek yang diketahui itu. Akhirnya rangsangan yakni objek yang telah diketahui dan disadari sepenuhnya tersebut akan menimbulkan respons lebih jauh lagi, yaitu berupa tindakan (action) terhadap stimulus atau objek tadi (Notoatmodjo, 2003).

Dalam penelitian Roger dalam Notoatmodjo (2003) mengungkapkan bahwa sebelum orang mengadopsi perilaku baru, didalam diri orang tersebut terjadi proses yang berurutan yaitu awareness (kesadaran), interest (merasa tertarik), evaluation (menimbangnimbang), trial (mencoba) dan adoption dimana seseorang telah berperilaku baru sesuai dengan pengetahuan, kesadaran dan sikapnya terhadap stimulus.

Pendapat tersebut sesuai dengan hasil dari penelitian dimana para kader yang telah mendapatkan informasi dan pelatihan telah berusaha untuk mencoba (trial) dan berusaha mengadopsi semua pengetahuan yang didapat untuk diterapkan saat posyandu tetapi karena terkendala oleh berbagai kondisi seperti; sarana dan prasarana, jumlah kader yang kurang, banyak kader yang sudah lansia sehingga pengetahuan mereka tidak dapat digunakan secara sepenuhnya saat posyandu. Karena kondisi ini terjadi secara berulang akhirnya tidak terbentuk suatu perilaku baru yang seharusnya inilah yang mengakibatkan pada saat pelaksanaan posyandu sistem lima meja tidak berjalan dengan baik.

Hal ini sesuai dengan pendapat dari Notoadmojo (2003), apabila perilaku baru atau adopsi perilaku di dasari oleh pengetahuan, kesadaran dan sikap yang positif, maka perilaku tersebut akan bersifat langgeng. Sebaliknya apabila perilaku tidak di dasari oleh pengetahuan dan kesadaran maka tidak akan berlangsung lama.

Dari pernyataan tersebut jelas bahwa perilaku tidak hanya ditentukan oleh faktor pengetahuan seseorang saja tetapi yang lebih penting adalah faktor kesadaran dan sikap yang positif serta dukungan lingkungan yang memadai untuk melakukan perilaku tersebut.

\section{Kesimpulan}

1. Tingkat pengetahuan tentang pelaksanaan system lima meja masih kurang.

2. Pelaksanaan system lima meja diposyandu masih kurang atau belum optimal.

3. Tidak ada hubungan antara pengetahuan kader posyandu dengan pelaksanaan system lima meja di Posyandu Balita Kelurahan Ngronggo Kota Kediri. 


\section{Saran}

1. Diharapkan diadakan pelatihan pada semua kader posyandu tentang pelaksanaan system lima meja.

2. Peningkatan penyediaan sarana dan prasarana di posyandu.

3. Perlu dilakukan pelatihan tentang promosi kesehatan terhadap kader posyandu.

\section{Daftar Pustaka}

Anonym, (2002). Senam Hamil, (http://www.suaramerdeka.com), diakses 20 april 2009.

Arikunto, Suharsimi. (1998). Prosedur penelitian suatu pendekatan praktek. Jakarta: PT Rineka Cipta

Azwar, Saifuddin. (2007) Sikap manusia teori dan pengukurannya. Yogyakarta: Pustaka Pelajar.

Dinkes Kota Surabaya, (2008) Tingkatkan kemampuan kader berikan penyuluhan, file:///optimalkanposyandu-lima-meja.html, diakses tanggal 3 juni 2009

Nursalam, (2003). Konsep dan penerapan metodologi penelitian ilmu keperawatan: Pedoman skripsi, tesis dan instrument penelitian keperawatan, Jakarta: Salemba Medika.

Notoatmodjo, Soekidjo (2003) Ilmu kesehatan masyarakat. Jakarta: PT Rineka Cipta.

Purwanto. Heri (1999) Pengantar perilaku manusia untuk keperawatan. Jakarta: EGC.

Riduwan (2004). Metode dan tehnik menyusun tesis. Bandung : Alfabeta.

Santoso, Singgih. (2004). Mengatasi berbagai masalah statistic dengan SPSS versi 11.5. Jakarta: PT Elek Media Komputindo.

Niven, N. (2002). Psikologi kesehatan: Pengantar untuk perawat dan professional kesehatan lain. Jakarta: EGC.

Suliha, U. dkk. (2002). Pendidikan kesehatan dalam keperawatan. Jakarta: EGC.

Walgito, B. (2002). Pengantar Psikologi umum. Yogyakarta: Penerbit Andi. 